\title{
Patient satisfaction levels in dental health care: a case study of people in North Mamuju, Indonesia 2017
}

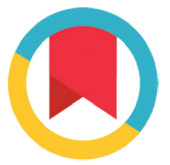

CrossMark

\author{
Fuad H. Akbar, ${ }^{*}$ Burhanuddin D. Pasiga, Rasmidar Samad, Ikhlas Bakri
}

\section{Abstract}

Objective: This research aims to describe the level of patients satisfaction in dental health services, study of people in North Mamuju Regency, West Sulawesi of Indonesia.

Material and Methods: Patient satisfaction is a useful measure that can be used to evaluate the service quality. Satisfaction is a comparison between the perceptions of services received with expectations, while the quality of health services is act or services provided by one party to another in form of care or provision of health facilities. To improve the quality of a health service that is necessary to do research on the level of patient satisfaction in dental health care.
Results: This research is Pathfinder Method Survey. Descriptive observational research with cross-sectional study design, population of the entire community of District Sarjo and Bambaira, North Mamuju West Sulawesi of Indonesia and research subjects were aged $>18$ years. The study found dimensions of empathy shows that 43 (100\%) respondent satisfied while dimensions of assurance most not satisfied that $4(14,0 \%)$ respondent.

Conclusion: Patient satisfaction is highest in the dimension of empathy then the dimensions of physical appearance, dimensional medical services followed responsiveness, and the last on assurance dimensions.
Department of Dental Public Health, Faculty of Dentistry, Hasanuddin University, Makassar, Indonesia
*Corresponding to: Fuad H. Akbar, Department of Dental Public Health, Faculty of Dentistry, Hasanuddin University, Makassar, Indonesia fuadgi2@gmail.com

Received: 2 January 2018 Revised: 3 January 2018 Accepted: 25 July 2018 Available Online 1 August 2018

Keywords: Patient satisfaction, Service quality, Dental care, Physical appearance, Medical services

Cite this Article: Akbar HH, Pasiga BD, Samad R, Bakri I. 2018. Patient satisfaction levels in dental health care: a case study of people in North Mamuju, Indonesia 2017. Journal of Dentomaxillofacial Science 3(2): 115-118. D0I: 10.15562/jdmfs.v3i2.694

\section{Introduction}

Service quality of health is largely determined by health care facilities and health services provided by health workers who are inside. The dentist is one of the health workers in providing health care must always maintain the quality of services in accordance with competency standards set by professional organizations. By the standards of competence expected that dentists can provide health services to the community with a quality that is almost the same. Nowdays quality is a challenge for organizations / health facilities to satisfy their patients and to evaluate the quality is important to be informed to the government..$^{1-3}$

Patient satisfaction is the most important thing that must be achieved by each health centers. Patient satisfaction with dental health services is the ratio between the patient's perception of the service received/after being served with patient expectations before getting service. If the patient's expectations are met, it means the service has been providing quality health care quality that makes an outstanding quality and will also lead to high satisfaction. ${ }^{4-6}$ Patient satisfaction is a useful measure that can be used to evaluate the service quality.
North Mamuju regency is the result of the division of Mamuju. Based on data from the North Mamuju regency health dentist ratio is 3.93 per 100,000 population in 2015 , while a target of achieving Healthy Indonesia shows that the health worker in this case the dentist has not reached the target that should the 11 per 100,000 population according to $\mathrm{WHO}$, while the ratio of dentists recommended is 1: 7500. The number of health centers in 2015 in all regions of North Mamuju regency as many as 15 units. Based on these data indicate that there is still shortage of dentists in North Mamuju. ${ }^{7,8}$

Based on the above North Mamuju Regency is new and not yet have health research data, especially in dental health services. To improve the quality of a health service that is necessary to do research on the level of patient satisfaction in dental health care. Dentist data indicate that there is still shortage of dentists in North Mamuju and have association with service quality that is influence about patient satisfactions level.

This research aims to describe the level of patients satisfaction in dental health services, study of people in North Mamuju Regency, West Sulawesi of Indonesia. 


\section{Material and Methods}

\section{Design and Method \\ Pilot pathfinder survey \\ Research Population and Sample}

The population in this study was the whole community of Sarjo District and Bambaira District in North Mamuju. The sample were people aged $>18$ years and totaling 43 samples.

\section{Variable dan Measurement}

Patient's satisfaction using questionnaire. ${ }^{9}$ Criteria of research which uses questionnaire used is a questionnaire containing about patient characteristics (age, gender, ethnicity, and educational level). Questionnaire consisting of five dimensions include empathy, assurance, responsiveness, physical appearance, and medical service.

Client's satisfaction measured through one item with five points scale by likert ( $1=$ very dissatisfied, $2=$ not satisfied, $3=$ quite satisfied, $4=$ satisfied, and $5=$ very satisfied). In result of this research use two course that satisfied ( very satisfied and satisfied) and not satisfied ( quite satisfied, not satisfied, and very dissatisfied). Patients assess these items by marking number in accordance with their answers. This use to describe overall satisfaction based on answer each dimensions while total score use to describe overall of patients satisfaction based on dimensions. If answer $60-100 \%=$ satisfied but $<60 \%=$ not satisfied .

\section{Data collection and analysis}

Data collected during two days. Data obtained through structured questionnaires which have been

\section{Table 1 Patients demographic characteristic}

\begin{tabular}{llll}
\hline Demographic Characteristic & \multicolumn{1}{c}{ N } & \multicolumn{1}{c}{$\%$} \\
\hline \multirow{4}{*}{ Age (years) } & $18-25$ & 12 & 27.9 \\
& $26-35$ & 9 & 20.9 \\
& $36-45$ & 10 & 23.3 \\
& $46-55$ & 8 & 18.6 \\
Gender & $56-65$ & 3 & 7.0 \\
& $>65$ & 1 & 2.3 \\
Ethnic & Male & 16 & 37.2 \\
& Female & 27 & 62.8 \\
& Mandar & 32 & 74.4 \\
\multirow{3}{*}{ Educational Level } & Bugis & 8 & 18.6 \\
& Kaili & 3 & 7.0 \\
& No Schooling & 16 & 37.2 \\
& Primary School & 18 & 41.9 \\
& Junior High School & 6 & 14.0 \\
& Senior High School & 3 & 7.0 \\
\hline
\end{tabular}

Source : primary data, 2017 designed specifically for the study. Questionnaire items have two main parts: the characteristics of the respondents and patient satisfaction level. Before starting the study, it was necessary to obtain permission from local authorities. To ensure the confidentiality of study participants, they were instructed not to provide personal identification in any form. Data collected were describe using SPSS (v22). Client demographic characteristics were analyzed descriptively using frequencies and percentages.

\section{Results}

Table 1 age of most of the respondents are aged between $18-25$ years of the $12(27.9 \%)$. female gender is more that $27(62.8 \%)$ of respondents, while mandated a tribe most namely $32(74.4 \%)$ of respondents while the show. Elementary Education last most of the 18 (41.9\%) of respondents.

Based on table 2 shows that the question of working procedures highest explanation that 26 (60.5\%) of respondents answered most satisfied and dissatisfied to questions about the explanation easier to understand the results of the $24(55.8 \%)$ respondents.

Based on table 3 the highest satisfaction to the question of service delivery regardless of the social status of the $32(74.4 \%)$ of respondents were not satisfied, while most of the questions the clarity provides care instructions before the $25(32.6 \%)$ of respondents.

Based on table 4 at most respondents answered satisfied with the responsiveness to questions dentist responsiveness in resolving complaints of patients were $26(60.5 \%)$ of respondents, while most are not satisfied with the speed of the dentist to deal with complaints of patients at $24(55.8 \%)$ of respondents .

Based on patient satisfaction table 5 by the dimension of the physical appearance at most to answer questions appearances satisfied the dentist as many as $31(72.0 \%)$ and most respondents answered dissatisfied 19 (44.2\%) of respondents to the question of cleanliness and tidiness of the treatment room.

\section{Discussion}

Women and age young adults more dental clinic visits. ${ }^{10,11}$ Based on research that assesses five dimensions indicate that there is no relationship between the average value of patient expectations with their perceptions in the category of age, gender, and education level. ${ }^{12}$

Most satisfied assurance dimension to questions about the working procedure while the explanation 
Table 2 Distributions of sample satisfaction based on dimensions of assurance

\begin{tabular}{|c|c|c|c|c|}
\hline \multirow[b]{2}{*}{ Dimensions of Assurance } & \multicolumn{2}{|c|}{ Satisfied } & \multicolumn{2}{|c|}{ Not Satisfied } \\
\hline & $\mathbf{n}$ & $\%$ & $\mathbf{n}$ & $\%$ \\
\hline Confidentiality of the disease the patient is awake & 23 & 53.5 & 20 & 46.5 \\
\hline Explanation of working procedures/actions & 26 & 60.5 & 17 & 39.5 \\
\hline $\begin{array}{l}\text { Ability and knowledge of dentist handle patient } \\
\text { complaints }\end{array}$ & 20 & 46.5 & 23 & 53.5 \\
\hline The explanation is easy to understand test results & 19 & 44.2 & 24 & 55.8 \\
\hline
\end{tabular}

Source : primary data, 2017

Table 3 Distributions of sample satisfaction based on dimensions of empathy

\begin{tabular}{|c|c|c|c|c|}
\hline \multirow[b]{2}{*}{ Dimensions of Empathy } & \multicolumn{2}{|c|}{ Satisfied } & \multicolumn{2}{|c|}{ Not Satisfied } \\
\hline & $\mathbf{n}$ & $\%$ & $\mathbf{n}$ & $\%$ \\
\hline $\begin{array}{l}\text { The attitude of seriousness dentists in checking } \\
\text { and dealing with patient complaints }\end{array}$ & 29 & 67.4 & 14 & 32.6 \\
\hline Service delivery regardless of social status & 32 & 74.4 & 14 & 25.6 \\
\hline Attention dentists in providing services & 29 & 67.4 & 11 & 32.6 \\
\hline Clarity provides information about disease & 29 & 67.4 & 11 & 32.6 \\
\hline Clarity provides instruction before treatment & 18 & 41.9 & 25 & 58.1 \\
\hline Clarity provides instruction about after treatment & 23 & 53.5 & 20 & 46.5 \\
\hline $\begin{array}{l}\text { Clarity of information and attitudes administrative } \\
\text { officer }\end{array}$ & 21 & 48.8 & 22 & 51.2 \\
\hline
\end{tabular}

Source : primary data, 2017

Table 4 Distributions of sample satisfaction based on dimensions of response

\begin{tabular}{|c|c|c|c|c|}
\hline \multirow[b]{2}{*}{ Dimensions of Response } & \multicolumn{2}{|c|}{ Satisfied } & \multicolumn{2}{|c|}{ Not Satisfied } \\
\hline & $\mathbf{n}$ & $\%$ & $\mathbf{n}$ & $\%$ \\
\hline The quick a dentist handle patient complaints & 19 & 44.2 & 24 & 55.8 \\
\hline $\begin{array}{l}\text { Responsiveness dentists in resolving patient } \\
\text { complaints }\end{array}$ & 26 & 60.5 & 17 & 39.5 \\
\hline The quick of the administration in providing service & 23 & 53.5 & 20 & 46.5 \\
\hline
\end{tabular}

Source : primary data, 2017

Table 5 Distributions of sample satisfaction based on dimensions of physical appearance

\begin{tabular}{|c|c|c|c|c|}
\hline \multirow[b]{2}{*}{ Dimensions of Physical Appearance } & \multicolumn{2}{|c|}{ Satisfied } & \multicolumn{2}{|c|}{ Not Satisfied } \\
\hline & $\mathbf{N}$ & $\%$ & $\mathbf{n}$ & $\%$ \\
\hline Appearance dentist & 31 & 72.0 & 12 & 28.0 \\
\hline Cleanliness infirmary & 25 & 58.1 & 18 & 41.9 \\
\hline Neatness infirmary & 24 & 55.8 & 19 & 44.2 \\
\hline Cleanliness waiting room & 24 & 55.8 & 19 & 44.2 \\
\hline $\begin{array}{l}\text { Cleanliness equipment to check the patients } \\
\text { teeth }\end{array}$ & 26 & 60.5 & 17 & 39.5 \\
\hline Completeness of Equipment & 26 & 60.5 & 17 & 39.5 \\
\hline
\end{tabular}

Source : primary data, 2017 explanation examination results is a question that most answered dissatisfied. This indicates that the dentist had explained the stages of work to care but is still lacking in terms of explanation of the examination results. Doctors have an important role in service satisfaction in terms of both consultation and communication at the time of inspection as well as using language that is easily understood by patients. ${ }^{13}$

Dimensions of empathy most satisfied on the question about service delivery regardless of social status while the most dissatisfied with the question clarity provides instruction before treatment. Culture greatly affect the service in this case has aspects compassionate. The interaction between patients and providers in this case the dentist is important because it is very influential in improving patient satisfaction with the service they get included instruction before and after treatment. ${ }^{14,15}$

Based on the dimensions of responsiveness of respondents answered satisfied most of the questions regarding the responsiveness of dentists in resolving patient complaints, while most are not satisfied with the speed of dentists handle patient complaints. Dental care and oral contrast to health care in general because it is focused on providing real care as the procedure performed on a patient at the dental clinic, need to follow-up or intervention while on a visit a general practitioner in which the focus is the patient may only receive consultation, control and only prescription the only remedy. It shows that intervention is one of the things being done to resolve patient complaints even though the speed to resolve complaints vary because of treatment at the dentist takes many more time. ${ }^{14}$

Patient satisfaction is based on the physical dimensions of the physical appearance at most satisfied to answer questions appearances the dentists and the most dissatisfied answer questions regarding cleanliness and neatness of the treatment room. Dimensions physical appearance in this case the most influential dentists and related to satisfaction and perceived service quality. Positive and significant impact on the dimensions of comfort (physical appearance) to client satisfaction one direct evidence that there is comfort in the waiting room services and the patient will directly assess the neatness and cleanliness. ${ }^{16-18}$

Satisfaction is based on the dimensions of the medical services most satisfied respondents who answered the question the benefits of the services provided as much and most are not satisfied with the effectiveness of medical services. The effectiveness of its service waiting times before treatment because each patient requires a long time to do treatment. ${ }^{13}$ 
Based on the dimensions most satisfied is dimensions of empathy. Empathy is an important component, especially concerning cognitive covers understanding emotions, experience, and capacity to communicate with the intention of helping to reduce the pain or the patients complaints. Other studies have shown that patient with dental care that assurance and empathy are important determinants of service quality dimensions of empathy have a huge impact on the determinants $16.46 \%$ on patient satisfaction with the service of hospital, followed by dimensions of the assurance $16.19 \%$, followed by dimensions of effectiveness $15.62 \%$ and dimensions of response $6.9 \%$ of determinants patient satisfactions with the service in health centers. In this study dimensions assurance most not satisfied. Dentist are more focused on providing care rather than explaining treatment procedures to minimize the time that treatment in health centers. ${ }^{19}$

In a competitive global world, the hospital can successfully apply the appropriate repair service process. This leads to the question related to what and how the quality of service should be improved and patient satisfaction. Therefore it is very important to know how to improve the quality of services for all dimensions in line with expectations and perceptions of patients. The behavior of doctors have an important role in patient satisfaction, followed by the availability of medicines, hospital infrastructure, staff conduct, and medical information. The main reason the patient back to a health facility is a satisfaction for physicians, hospitals, interaction with patients, nurses, and hospital facilities. Thus identifying factors that can increase patient satisfaction that is useful to improve the quality of service is very important, especially in health facilities. ${ }^{20}$

\section{Conclusion}

Patient satisfaction is highest in the dimension of empathy then the dimensions of physical appearance, dimensional medical services followed responsiveness, and the last on assurance dimensions.

\section{Aknowledgment}

Authors are also grateful to the Dean of Faculty of Dentistry Hasanuddin University for their support and assistance.

\section{Conflict of Interest}

The authors report no conflict of interest.

\section{References}

1. Adebayo ET, Adesina BA, Ahaji LE, et al. Patient assesment of the quality of dental care services in a Nigerian Hospital. J Hospital Adm 2014;6: 24-26.

2. Aghamolaei T. Service quality assesment of referral hospital in southern iran woth servqual technique: patients perspective. BMC 2014;14: 1.

3. Al-Fraihi KJ, Latif SA. Evaluation of outpatient service quality in eastern saudi arabia. Saudi Med J 2016;37: 425.

4. Ali D. Patient satisfaction in Dental Healthcare Centers. Euro J Dentist 2016;10: 309-314.

5. Amole BB, Oyatoye EO, Kuye OL. Determinations of patients satisfaction on service quality dimensions in the Nigeria teaching Hospitals. Zeszyty Naukowe 2016;87: 16.

6. Aulia R, Adhani R, Taufiqurrahman I, et al. Pengaruh kualitas pelayanan kesehatan gigi dan mulut terhadap kepuasan pasien BPJS di layanan primer Banjarmasin. Dentino Jurnal Kedokteran Gigi 2017;2: 9.

7. Bata YW, Alwi, Darmawansyah. Hubungan kualitas pelayanan kesehatan dengan kepuasan pasien pengguna askes sosial pada pelayanan rawat inap di RSUD lakipadada kabupaten tana toraja tahun. Makassar: Universitas Hasanuddin; 2013. p. 6-9.

8. Bhat et al. Asessment of satisfaction levels of patient during dental outreach programs in rural part of udaipur, India. Nigerian Postgraduate Med J 2016;23: 227.

9. Chang WJ, Chang YS. Patient satisfaction analysis : identifying key drivers and enhancing service quality of dental care. J Dent Sci 2013;8: 239.

10. Devi KV, Muthuswamy PR. A study on service quality gap in multy specialty hospitals. Indian J App Res 2016;6: 616-617.

11. Flickinger TE. Clinical empathy is associated with differencesin patient-clinician communication behaviours and higher medication self efficacy in HIV care. PEC 2016;99: 224-225.

12. Akbar FH, Pratiwi R. Patient satisfaction against the quality of dental health services at dental polyclinic of Tenriawaru General Hospital in Bone Regency. J Dentomaxillofac Sci 2016;1: 177-184

13. Makarem J. Patients satisfaction with inpatient services provided in hospitals affiliated to Tehran University of Medical Sciences, Iran, during 2011-2013. J Medic Ethics \& History Med 2016;9: 7-9.

14. Mohebifar R, Hasani H, Barikani A, et al. Evaluating service quality from patients perception: application of importance performance analysis method. Osong Public Health Res Perspect 2016;7: 234

15. Mthethwa SR, Chabikuli NJ. Comparing repeat and first visit patients' satisfaction with service quality at medunsa oral health centre. SADJ 2016;71: 458.

16. Nagappan N, John J. Patient satisfaction with the dental service offered by a dental hospital in india. J Indian Assoc Public Health 2014;12: 297.

17. Nejati AA, Ansarimoghadam ZS. Factor selection for service quality evaluation: a hospital case study. Int J Health Care Quality Assurance 2017;30: 1.

18. Pramanik A. Patients perception of service quality of health care services in India: a comparative study on urban and rural hospitals. JHM 2016;18: 212.

19. Rapidah A, Nurulhuda A, Suhaila Y. A comparative study of service quality on patient satisfaction between public hospital in johor bahru, malaysia. SCIREA J Agriculture 2017;1:206.

20. Ratnam E. Determinants of patient satisfaction in hospital. Europ J Business \& Management 2017;7: 1.

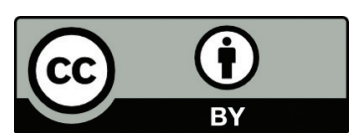

This work is licensed under a Creative Commons Attribution 